\title{
Algumas sugestões para a reforma da Legislação Judiciaria Civil
}

Spencer Vampré

As queixas, que diariamente surgem nas conversações e na imprensa periódica, a respeito da morosidade e da incerteza das aplicações do direito, recaem, em sua maior parte, sobre as regras do processo, cuja observância muitas vezes destroe a realidade prática do direito substantivo. Si me assiste um direito pessoal ou real, e perco a demanda, que intentei para torná-lo respeitado e eficaz, praticamente se desmentiu aquele meu direito, pois o Estado não acudiu com a sanção pronta que o meu interesse individual e a vida social exigem. Quaisquer sugestões, portanto, que visem tornar a discussão judicial mais pronta, mais segura e mais econômica, devem merecer acolhida simpática, e a colaboração dos que creem no progresso indefinido das instituições humanas.

\section{AS NULIDADES}

Comecemos por um dos capítulos mais complexos do direito processual - o das nulidades. Devemos considerar, em primeira linha, que a própria existência de nulidades, em atos solenemente praticados sob as vistas dos juizes, constitue uma aberração, dado que aos juizes assistem conhecimentos juridicos elementares, e todos os atos são notificados á parte adversa. Dever-se-ão consignar no codigo do processo civil estes princípios fundamentais, salva a redação: 
Art. A parte, contra quem se quizer que produza ef eitos qualquer ato judicial defeituoso, poderá pedir ao Juiz que o declare ineficaz, enquanto se não sanar o defeito que o inquine.

$\S 1$. A nulidade de qualquer ato judicial só a este abrange, e será sanada logo que, alegada, assim o ordene o Juiz, observadas as solenidades preteridas.

$\S 2$. Si os autos se acharem conclusos para sentença, em primeira ou segunda instância, converter-se-á o julgamento em diligência para serem supridas as nulidades do ato defeituoso, ou se realisar este de novo, sem prejuizo de todos os outros atos judiciais subsequentes, que não forem decisórios.

Parece-nos que si se adotar como critério fundamental que o Juiz de primeira, ou segunda instância, tem o dever, e o direito, de sanar todas as nulidades apontadas pela parte a quem prejudica, e que estas não importam a ineficácia dos atos informativos, mas apenas a da decisão, ter-se-á simplificado o processo civil, extirpando-lhe um dos mais sérios e invenciveis defeitos.

Cumpre assinalar que o processo judicial não é mais que uma discussão ordenada e não arbitrária para descoberta da verdade dos fatos e reta aplicação do direito. Não se poderá negar, sob suspeita de possivel parcialidade do Juiz, que este providencie pela exata observância de todas as formalidades, e mesmo pela repetição de atos, uma vez inquinados de defeitos que prejudicarão o seu julgamento futuro, ou o do Tribunal ad quem.

Esta matéria é complexa, e, uma vez que visamos apresentar "sugestões", parece-nos mais conveniente atingir outros 
problemas do que nos emaranharmos em regras processuais secundárias, tendentes á perfeita realisação dos principios expostos.

Toquemos outro ponto:

\section{OS RECURSOS}

Nada pode haver mais chocante, mais flagrantemente injusto, mais revoltantemente anti-social e anti-juridico, do que deixar o Tribunal Superior de tomar conhecimento de um recurso por não ser cabivel, ou por falta de formalidades processuais no respetivo instrumento, ou por ter sido interposto com errôneo fundamento. Desde que a parte recorreu, pagou as custas, a parte adversa foi ouvida, e o Juiz deu a sua decisão confirmatória da decisão recorrida, nada deve impedir ao Tribunal Superior de entrar no mérito do recurso, uma vez que a sua função primordial é administrar justiça, corrigindo o erro judiciário ou a injustiça da decisão, ou ainda provendo á segurança de um direito. Não ha, a nosso ver, mais dramático espetáculo do que o que assistimos todos os dias - não se tomar conhecimento de um recurso, porque este não era cabivel, porém um outro, quando é certo que a parte recorreu, e que o Juiz entendeu de mandar segui-lo. Não vêem os Juizes de Segunda Instancia que estão assim matando o direito, por amor á formalidade processual? Para evitar tal inconveniente propomos o seguinte princípio:

Art. De qualquer decisão do Juiz, poderá a parte recorrer por instrumento, e sem efeito suspensivo, para o Tribunal Superior. Este, tendo elementos para decidir, julgará logo, confirmando ou reformando a decisão recorrida, e não os tendo mandará preliminarmente que o recorrente os supra, intimada a parte adversa.

Esta sugestão visa acabar com a nefasta distinção entre apelação e agravo, havendo apenas recurso, sem efeito 
suspensivo. Acrescentariamos que, em casos especiais, e para evitar consideravel dano ao recorrente, poderia o Juiz exigir do recorrido que segurasse o recorrente de qualquer dano que a execução imediata da decisão lhe possa causar, caso não venha a ser confirmada. Si se receiar abandonar a tradição, poder-se-á manter ao recurso da decisão final do Juiz o efeito suspensivo, e a todos os outros o efeito devolutivo, podendo, entretanto, o Juiz suspender a execução ou dar execução imediata, si a parte interessada o reclamar e der segurança á outra do resarcimento do dano eventual.

\section{ATOS SOB PROTESTO}

Outra sugestão: - permitir á parte interessada praticar qualquer ato de instrução do processo (inquirição de testemunhas, exames, vistorias, depoimento da parte adversa, precatórias, etc.),embora a parte adversa se oponha, desde que a requerente pague as custas, e não haja suspensão do andamento do feito. Estes atos serião praticados sob protesto. Exemplifiquemos para melhor compreensão: - 0 autor quer ouvir uma testemunha. $O$ réu pretende que se acha exgotada a dilação probatória. Ou o autor quer que os peritos respondam a um quesito. $O$ réu se opõe a esse quesito por ser impertinente. O Juiz dá razão ao autor, e decide que a testemunha não deve ser ouvida, ou o quesito não deve ser respondido. Pois bem: o autor poderá pedir que se faça sob protesto, isto é, pagará as custas respetivas, e pleiteará que no julgamento em primeira ou segunda instância se aprecie a admissibilidade, ou inadmissibilidade, da prova requerida. Parece-nos isso muito mais lógico, e mais pronto, do que interromper o processo, interpor agravo, e levar ao Tribunal Superior prematuramente uma questão que ele poderá apreciar de futuro sem prejuizo para ninguem, e ainda com a vantagem de maior abundância de elementos de discussão. 
Outra sugestão, e esta da maior simplicidade, é a que consiste na triplicação dos autos, mediante a máquina de escrever: - todo e qualquer articulado, requerimento, ato probatório, ordinatório ou decisório, é feito á máquina em três exemplares, ficando o original em cartório donde nunca sai a não ser para a sentença ou despacho do Juiz, e sendo as duas cópias, autenticadas pelo escrivão, entregues a cada uma das partes, ou (sendo elas muitas) áquela que fôr encarregada por todas de recebê-las.

Parece-nos que os artigos seguintes englobam as regras dominantes :

Art. 1. Todos os processos cíveis serão dactilografados de acôrdo com os dispositivos da presente lei, podendo ser feitos em papel carbono os exemplares ou cópias a que ela se refere.

Art. 2. Todos os articulados, requerimentos, alegações e cotas, feitos por um litigante, serão dactilografados em triplicata. Apresentados ao escrivão, depois de verificar este que os três exemplares conferem entre si, submeterá o primeiro deles ao despacho do juiz, e este porá tambem a sua rubrica nos dois outros. O escrivão guardará o primeiro exemplar em cartório, autoando-o juntamente com os documentos que o instruirem, e entregará o segundo ao autor e o terceiro ao réu, certificando neles o despacho exarado pelo juiz no primeiro, e certificando neste a entrega referida, da qual poderá exigir recibo.

A entrega da cópia a qualquer dos litigantes poderá ser tambem feita por oficial de justiça, praticadas as formalidades referidas, e a certidão da entrega será junta ao primeiro exemplar.

Art. 3. Todos os documentos, instrumentos, mapas e papeis, com que uma parte instruir os seus requerimentos, ou alegações, serão of erecidos jun- 
tamente com duas cópias, sendo o respetivo original junto aos autos, em cartório, e sendo cada uma das cópias entregues a cada um dos litigantes, depois de conferidas e com as formalidades do artigo anterior.

Art. 4. Sempre que houver mais de um autor ou réu, salvo si forem marido e mulher, o juiz, a requerimento de qualquer deles, ou sob representação do escrivão, indicará qual o advogado dos autores ou réus que em nome de todos receba as cópias.

$\S$ Unico. Poderão, entretanto, todos os litisconsortes obter do escrivão as cópias, pagando as respetivas custas.

Art. 5. Todos os termos de audiências, assentadas, depoimentos das partes, e testemunhas, e quaisquer outros, lavrados pelo escrivão e seus ajudantes, serão dactilografados em triplicata, á medida que se forem exarando.

$\S$ Único. O primeiro exemplar, assinado pelo juiz, pelo escrivão e pelas partes, ficará autoado em cartorio, e os dois outros, finda a audiência, serão entregues, depois de rubricados por todos, e pelo escrivão, a cada um dos litigantes, ou ao advogado indicado pelos autores ou réus, si forem mais de um.

Art. 6. Nas vistorias, arbitramentos, e outros exames periciais, será o laudo of erecido em três: exemplares dactilografados, sendo o primeiro autoado em cartorio e os demais entregues ás partes com as formalidades dos artigos precedentes.

Art. $7 \quad 0$ juiz dará a sua sentença em triplicata dactilografada, ficando o original em cartorio e sendo as cópias assinadas e rubricadas entregues ás partes com as mesmas formalidades. 
Art. 8. Para apresentar-se á instância superior não necessitará a parte de traslado, bastandolhe depositar em cartório todas as cópias que houver recebido, as quais, depois de ordenadas e conferidas pelo escrivão, ficarão autoadas em cartório, remetendo-se áquela instância os autos formados pelos primeiros exemplares.

Art. 9. Os autos formados pelos primeiros exemplares não sairão de cartório sob pretêsto algum, salvo para o juiz, mas poderão ser livremente consultados pelas partes ou por terceiros.

Art. 10. Quaisquer erros ou omissões não prevalecerão contra o teor dos autos que ficam em cartório, e dos documentos que os instruirem, pois devem as partes sempre conferí-los com as cópias que recebem, não se admitindo reclamações a respeito, uma vez decorridos os prazos em que podem reclamar contra os despachos, na conformidade das leis do processo.

Art. 11. Ao advogado ou procurador que cientemente e por mais de uma vez apresentar no mesmo feito cópias erradas, ou omissões, será vedado o direito de receber cópias e só terá vista dos autos em cartório. Si ainda reincidir na infração, poderá ser suspenso até 60 dias, e si ainda perseverar, ficará impedido de procurar na causa.

Art. 12. O escrivão, que for omisso ou negligente na extração e conferência das cópias, ficará sujeito ás penas disciplinares na conformidade da legislação vigente.

Art. 13. Continuarão a ser praticados todos os termos e fórmulas consagrados pelas leis do processo e pela praxe, no que não forem contrários á presente lei, revogadas as disposições em contrário. 


\section{OS ESCRIVÃES}

Cumpre considerar agora outro aspeto do problema processual. Nunca se conseguirá rápido andamento dos feitos, enquanto subsistir o monopólio dos escrivães. A observação diária nos ensina que os prazos forenses se dilatam indefinidamente pela pouca atividade dos escrivães ou escreventes, que, trabalhando por distribuição, não têm interesse em se tornarem mais operosos. Neste ponto, nas comarcas de maior movimento, a lei de organisação judiciária poderá criar tantos escrivães quantos sejam necessários para o movimento dos feitos, e ainda admitirá que qualquer escrivão possa funcionar em qualquer ato judicial. Haverá, assim, uma distribuição inicial para o escrivão-secretário do Juizo, que será o encarregado de guardar os autos originais e juntar-lhe todos os termos lavrados por ele próprio, e pelos outros. Mas, qualquer escrivão disponivel poderá ser chamado para dactilografar o termo processual requerido pelas partes, recebendo por isso os emolumentos respetivos, e entregando ao escrivão-secretário o original, e ás partes as cópias, como ficou referido acima.

Os escrivães-secretários terão a guarda dos autos de cada Juizo, conforme distribuição, e os escrivães comuns terão escritórios como os tem os advogados, mas só poderão praticar os atos do seu ofício no edifício do Forum e na presença do Juiz. Nas comarcas de grande movimento poder-se-ão criar Juizes especiais para presidir aos atos instrutórios do processo.

Teremos assim as vantagens de extinguir o odioso monopólio dos escrivães, de incentivar maior provento aos mais ativos e enérgicos, e de acelerar o. andamento dos feitos, condição cada vez mais imperiosa num mundo, como o atual, em que o tempo adquire progressivamente maior valor.

Finalmente uma última sugestão: 


\section{O CALENDÁRIO JUDICIAL}

A triplicação dos autos, e a possibilidade de realisar os termos judiciais, não só com o escrivão-secretário, mas com quaisquer outros, tornam possivel instituir o calendário judicial, isto é, a prefixação do tempo em que serão praticados todos os atos de cada demanda. Assim, proposta uma ação no dia 2 de Máio, o escrivão-secretário organisará desde logo as datas de início e de terminação de cada uma das fases da demanda, por exemplo - contestação até 12 de Máio; réplica até 22 de Máio; tréplica até 1 de Junho; dilação probatória até 22 de Junho; razões do autor até 2 de Julho; razões do réu até 12 de Julho; sentença do Juiz até 12 de Agosto.

Claro está que as exceções deverão ser apresentadas conjuntamente com a contestação, bem como a reconvenção. Recebida a exceção, dilatória ou peremptória, poderá o autor pedir que, não obstante, se prosiga na demanda, si não preferir aguardar o pronunciamento do Tribunal Superior, no recurso que interpuzer.

Rejeitada a exceção, poderá a sua matéria ser apreciada conjuntamente com o mérito, salvo si o excipiente tiver recorrido ao Tribunal Superior e este tiver confirmado a sua rejeição.

Como ficou explicado, o Tribunal Superior não anulará o processo, em virtude da decisão sobre as exceções, mas apreciará tambem o mérito, e aproveitará todos os atos de instrução, que não ficarem prejudicados.

Poderá parecer que muito inovamos com estas sugestões. Mas, uma idéia dominante poderá orientar e iluminar a quem quizer adotá-las - a de que é necessário economisar o esforço dos que combatem pelo direito, tornando o direito judiciário civil uma verdadeira garantia dos direitos civis, e não, como até aqui tem sido tantas vezes, o guarda ilusório de sua segurança. 